\title{
Molecular Docking Studies of Compounds from Brucea javanica (L.) Merr. Towards the Discovery of Potential H5N1 Neuraminidase Inhibitors
}

\author{
Rina F. Nuwarda ${ }^{1}$, Zelika M. Ramadhania ${ }^{1}$, Imam A. Wicaksono ${ }^{1}$, Ade R. R. Firdaus ${ }^{2}$, \\ Muhammad Yusuf ${ }^{2}$, Muchtaridi Muchtaridi ${ }^{1}$ \\ ${ }^{1}$ Faculty of Pharmacy, Universitas Padjadjaran, West Java - Indonesia \\ ${ }^{2}$ Department of Chemistry, Universitas Padjadjaran, West Java - Indonesia
}

Submitted 11 January 2020; Revised 20 January 2020; Accepted 21 January 2020; Published 03 February 2020

*Corresponding author: rina.nuwarda@unpad.ac.id

\begin{abstract}
The occurrences of a highly pathogenic avian influenza virus (HPAI) type A H5N1 has caused infections in millions of poultry as well as hundreds of human cases and even mortalities. Indonesia has become one of the world's highest casualty rates of H5N1 human infections, with the number of deaths was 167 from a total of 199 cases. The development of viral resistance towards the available anti-influenza drugs neuraminidase (NA) inhibitors required the discovery of new inhibitors. In the recent advance of drug discovery, natural products have been considered as one of the essential sources of medicinal agents, and Brucea javanica has been found to possess antiviral activity against H5N1 NA. Thus, this research aimed to investigate the in silico activities of compounds from $B$. javanica using molecular docking methods against H5N1 NA. In this study, docking-based virtual screening of compounds from B. javanica to quickly select in silico hits to be potential NA inhibitors was performed. Subsequently, the intermolecular interactions of the inhibitor compounds with the H5N1 NA were analysed to examine the most preferred interactions. The results showed that brucein $\mathrm{G}$ and bruceoside $\mathrm{C}$ were found having the lowest binding energy and most preferred interactions with H5N1 NA and therefore, can be proposed for further study as potential NA inhibitors.
\end{abstract}

Keywords: antiviral, Brucea javanica, H5N1, molecular docking, neuraminidase

\section{Studi Penambatan Molekuler Senyawa-senyawa dari Brucea javanica (L.) Merr. Menuju Penemuan Inhibitor Potensial Neuraminidase H5N1}

\begin{abstract}
Abstrak
Kemunculan virus flu burung tipe A H5N1 yang sangat patogen telah menyebabkan infeksi pada jutaan unggas serta ratusan kasus infeksi pada manusia dan bahkan menyebabkan kematian. Indonesia merupakan salah satu kasus tertinggi infeksi H5N1 pada manusia di dunia, dengan jumlah kematian 167 dari total 199 kasus. Kemunculan resistensi virus terhadap obat anti-influenza neuraminidase (NA) yang tersedia membutuhkan penemuan inhibitor baru. Dalam penemuan obat baru-baru ini, senyawa bahan alam telah dijadikan salah satu sumber penting bahan obat, dan Brucea javanica telah diteliti memiliki aktivitas antivirus terhadap NA H5N1. Dengan demikian, penelitian ini bertujuan untuk menyelidiki aktivitas in silico senyawa dari B. javanica menggunakan metode penambatan molekuler terhadap NA H5N1. Dalam penelitian ini, dilakukan skrining virtual senyawa-senyawa dari B. javanica untuk memilih senyawa yang berpotensial menjadi penghambat NA. Selanjutnya, interaksi antar molekul dari senyawa inhibitor dengan NA H5N1 dianalisis untuk melihat interaksi yang paling disukai. Hasil penelitian menunjukkan bahwa brucein $\mathrm{G}$ dan bruceoside $\mathrm{C}$ ditemukan memiliki energi ikat terendah dan interaksi yang paling disukai dengan NA H5N1 dan oleh karena itu, dapat diusulkan untuk penelitian lebih lanjut sebagai inhibitor NA yang potensial.
\end{abstract}

Kata Kunci: antivirus, Brucea javanica, H5N1, penambatan molekuler, neuraminidase 


\section{Introduction}

H5N1, a highly pathogenic avian influenza (HPAI) virus, causes the infection to the human respirational tracks leading to pneumonia, acute respiratory disease and even death for a specific group of people such as children below five years of age, elderly, pregnant women, and those with chronic medical conditions. ${ }^{1,2}$ This virus remains to circulate amidst avian in some Asian and African countries, causing outbreaks in poultry as well as infections in human with high mortality. Since its recurrence in 2003 to 2019 , there have been 861 infection cases of $\mathrm{H} 5 \mathrm{~N} 1$ reported to $\mathrm{WHO}$, with 455 of these cases are fatal. ${ }^{3,4}$ Indonesia, Vietnam, and Egypt have reported having the maximum number of $\mathrm{H} 5 \mathrm{~N} 1$ infection cases to date. ${ }^{5,6}$ Indonesia is known to be an endemic country for $\mathrm{H} 5 \mathrm{~N} 1$ and said to have the highest number worldwide for fatal cases $\mathrm{H} 5 \mathrm{~N} 1$ infection in human with 199 cases and 168 deaths from 2003 to 2015. The majority of H5N1 human cases have been related to exposure to poultry through close or direct contact with the sick or dead ones. Meanwhile, the mortality cases have been associated with the late handling of health care or hospitalisation, delayed diagnosis and antiviral treatment. ${ }^{7}$

M2-ion channel inhibitors and neuraminidase (NA) inhibitors are the approved classes of antivirals for the treatment of influenza virus infections. NA inhibitors, antiviral drugs that inhibit the action of NA enzyme, were believed to have a higher tolerance, a wide-ranging spectrum of antiviral, and less likelihood for the appearance of viral resistance compared to the M2 inhibitor. ${ }^{8,9}$ Zanamivir and oseltamivir are NA inhibitors drugs which are already approved and commercially available for the treatment of influenza. Nevertheless, the poor oral bioavailability of zanamivir necessitates this drug to be administered by inhalation, whereas oseltamivir-resistant $\mathrm{H} 1 \mathrm{~N} 1$ viruses have arisen due to the latter extensive use as oral medication. Recently, laninamivir, a quite effective NA inhibitor, has been accepted for use in Japan. Unfortunately, its efficacy against oseltamivir-resistant NA in adults has not been confirmed. Due to this emerging resistance and reduced potency, more study is needed to find novel and more potent antiinfluenza agents. ${ }^{10,11}$

Natural products, especially those originated from plants, have been found in empirical medicine and generated the strategy for therapeutic of numerous diseases, including influenza, particularly avian flu H5N1. Several studies have demonstrated that some natural compounds possess antiviral activity. ${ }^{12,13}$ Brucea javanica L. Merr. is one of indigenous Indonesia plants and has been reported to have activity against $\mathrm{H} 5 \mathrm{~N} 1$ NA. ${ }^{14,15}$ Several chemical components have been isolated from the $B$. javanica, such as: bruceantin, bruceantinol, bruceantinoside $\mathrm{A}$, bruceine $\mathrm{A}$, bruceine $\mathrm{B}$, bruceine $\mathrm{C}$, bruceine $\mathrm{D}$, bruceine $\mathrm{E}$, bruceine $\mathrm{G}$, bruceoside $\mathrm{A}$, bruceoside B, bruceoside C, daucosterol, dehydrobruceantinol, dehydrobruceine A, dehydrobruceine B, dehydrobrusatol, yadanziolide $\mathrm{A}$, and yadanziolide $\mathrm{B} .{ }^{16-18}$ Although it has been reported that B. javanica possesses antiviral activity, there is still very lack of information regarding the compounds and their interactions with the NA enzyme in the molecular level. Therefore, this research aimed to investigate the in silico activities of several compounds from $B$. javanica which are available in the ZINC database using molecular docking methods against $\mathrm{H} 5 \mathrm{~N} 1$ NA.

\section{Methods}

2.1. Materials

Molecular docking simulation was performed using AutoDock 4.2 software attained from The Scripps Research Institute website (http://autodock.scripps. edu/downloads) running on Linux Ubuntu operating system. The visualization of docking results was carried out using Biovia Discovery Studio Visualizer (www.acceryls. com). B. javanica compound structures as ligands were downloaded from the ZINC database (http://zinc.docking.org/). For control docking experiment, the crystal structure of $\mathrm{H} 5 \mathrm{~N} 1$ avian influenza NA (PDB ID: 2HU4) complexed with oseltamivir 
carboxylate (OTV) was downloaded from the Research Collaboratory for Structural Bioinformatics (RCSB) Protein Data Bank website (www.rcsb.org).

\subsection{Methods}

\subsubsection{Positive Control docking}

The downloaded PDB (text) format of 2HU4 crystal structure was divided into two separate PDB files using Biovia Discovery Studio Visualizer, one comprising all the atoms of the NA enzyme as target macromolecule, the other comprising those of OTV as a ligand. The structures were then protonated using MGLTools 1.5.6. by adding Gasteiger charge to OTV, and Kollmann charges to NA structure. Both OTV and NA were saved in PDBQT format. OTV was redocked to NA with grid box dimension $60 \mathrm{x}$ $60 \times 60$, and coordinate $\mathrm{x}=0.324, \mathrm{y}=81.366$, and $\mathrm{z}=109.37$. Residues located in the range of $5 \AA$ around which play a significant role in the substrate-binding such as Arg118, Arg152, Arg292, Glu276 and Arg371 were selected. Control docking procedure was performed using following parameters: GA run $=100$, maximum number of evaluation $=5,000,000$, population size $=150$, and maximum generation $=27,000$. Control docking results were analysed based on their RMSD value.

\subsubsection{Molecular docking simulation}

Nineteen of $B$. javanica compound structures were downloaded from the ZINC database. The Kollmann charge was then added with the aid of MGLTools 1.5.6. The ligands were then saved in PDBQT format and the molecular docking simulation to screen the potential ligands was carried out using validated parameters from control docking. The required python script files for the preparation of compounds and virtual screening in AutoDockTools/Utilities24 were executed using pythonsh command. The visualisation of docking simulations was performed using Biovia Discovery Studio Visualizer, and the results were sorted based on the free energy of binding on the most populated cluster and their intermolecular interactions with NA. For this study, the top five compounds were selected based on their free energy binding and followed by the selection of two compounds with the most preferred interactions.

\section{Result}

Control docking experiment was carried out to validate the docking parameters which would be used in virtual screening of the $B$. javanica compounds. The best docking position of compounds was selected based on the most populated cluster, then followed by the form of intermolecular interaction taken place between ligand and receptor, subsequently the lowest binding energy after the docking search was completed. The simulation results showed that the structural deviation in term of RMSD value was 1.32 $\AA$ (Figure 1) and the docking simulation has generated three clusters in which the first

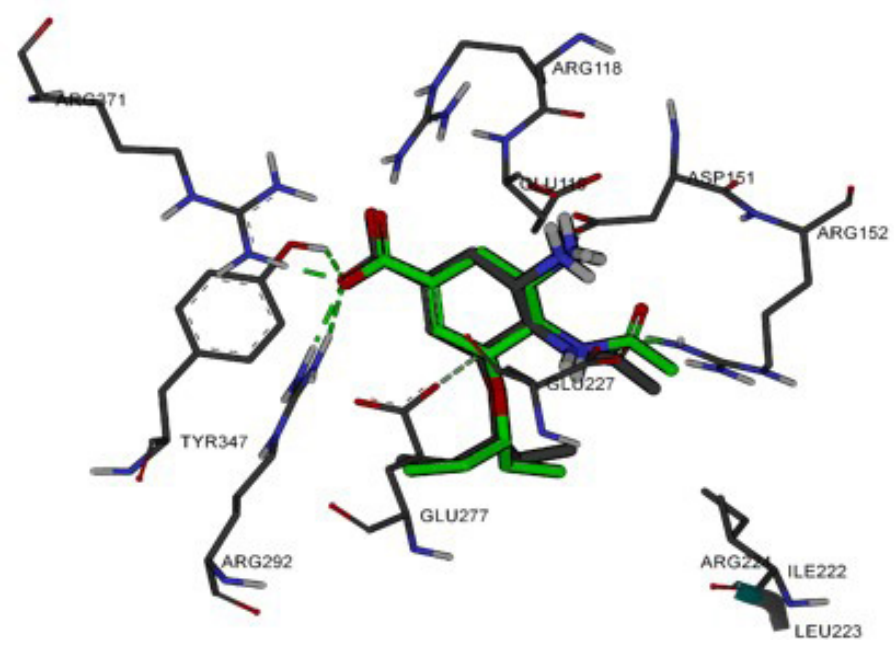

Figure 1. Superposition of the initial pose (grey colour) and the control docking pose (green colour) of OTV (PDB ID 2HU4) with RMSD value $1.32 \AA$. 
cluster was the most populated one with 94 conformations, followed by the second cluster with five conformations and the last cluster with only one conformation. From the most populated cluster, the structures with the lowest predicted free energy of binding $(-9.30 \mathrm{kcal} / \mathrm{mol})$, i.e. conformation no. 2 was selected.

Virtual screening was carried out to screen 19 ligands from $B$. javanica plant. The docking scores were then graded energetically, from the lowest to the highest. The results showed that bruceoside B generated the lowest binding energy with the value of -9.1 $\mathrm{kcal} / \mathrm{mol}$, followed by bruceantinol, bruceine $\mathrm{G}$, bruceoside $\mathrm{C}$, and bruceantin with the free energy binding value of $-8.65,-8.41,-8.39$, and $-8.17 \mathrm{kcal} / \mathrm{mol}$, respectively (Table 1 ).

As well as their free energy of binding, the ligands were also analysed based on their intermolecular interactions with the important amino acid residues in NA binding site such as Asp151, Arg152, Glu119, Glu227, Glu277, Arg292. Arg118, Arg371, and Tyr347. The interaction was then observed with the consideration of the similarity interaction with OTV as the control ligand, as shown in Table 2.

Based on the examination of the hydrogen bonding interaction between the five top compounds with NA binding site, brucein $\mathrm{G}$ and bruceoside $\mathrm{C}$ were found to have the most preferred interactions (Figure 2 and 3 ).

\section{Discussion}

Control docking is a means of choosing a crystal structure of a targeted macromolecule which already in-complex with a previously known ligand, splitting the ligand from the target protein, and docking it back to the "induced-fit" form of the protein. In this experimentation, positive control docking was conducted with the crystal structure of H5N1 NA in-complexed with OTV (PDB ID: 2HU4). The most populated cluster generated 94 conformations and was considered as the representative of the best possible position of OTV interaction with H5N1 NA binding site. The grouping of these docking simulation results was grounded on the RMSD (Root Mean Square Deviation)

Table 1. Docking simulation results of compounds from B. javanica demonstrated the binding energy of the compounds.

\begin{tabular}{ccc}
\hline No. & Name of compound & Free energy binding (kcal/mol) \\
\hline 1 & Bruceantin & -8.17 \\
2 & Bruceantinol & -8.65 \\
3 & Bruceantinoside A & -7.65 \\
4 & Bruceine A & -8.06 \\
5 & Bruceine B & -7.53 \\
6 & Bruceine C & -7.43 \\
7 & Bruceine D & -6.43 \\
8 & Bruceine E & -5.86 \\
9 & Bruceine G & -8.41 \\
10 & Bruceoside A & -6.94 \\
11 & Bruceoside B & -9.10 \\
12 & Bruceoside C & -8.39 \\
13 & Daucosterol & -7.24 \\
14 & Dehydrobruceantinol & -7.61 \\
15 & Dehydrobruceine A & -6.65 \\
16 & Dehydrobruceine B & -6.63 \\
17 & Dehydrobrusatol & -6.73 \\
18 & Yadanziolide A & -6.01 \\
19 & Yadanziolide B & -5.81 \\
\hline
\end{tabular}


Table 2. Hydrogen bonding interactions between ligands, including OTV with important residues in NA binding site.

\begin{tabular}{|c|c|c|c|c|c|c|c|c|c|c|}
\hline \multirow[b]{2}{*}{ Name of Compound } & \multicolumn{9}{|c|}{ Residues } & \multirow{2}{*}{$\begin{array}{c}\text { Similarity with } \\
\text { OTV }\end{array}$} \\
\hline & Asp & Arg & Glu & Glu & Glu & Arg & Arg & Arg & $\begin{array}{l}\text { Tyr } \\
347\end{array}$ & \\
\hline OTV & $\sqrt{ }$ & $\sqrt{ }$ & $\sqrt{ }$ & $\sqrt{ }$ & $\sqrt{ }$ & $\sqrt{ }$ & $\sqrt{ }$ & $\sqrt{ }$ & $\sqrt{ }$ & 9 \\
\hline Bruceantin & $\sqrt{ }$ & $\sqrt{ }$ & & $\sqrt{ }$ & & $\sqrt{ }$ & & & & 4 \\
\hline Bruceantinol & $\sqrt{ }$ & & & & & & $\sqrt{ }$ & $\sqrt{ }$ & & 3 \\
\hline Bruceantinoside A & $\sqrt{ }$ & $\sqrt{ }$ & & & $\sqrt{ }$ & & & & & 3 \\
\hline Bruceine A & $\sqrt{ }$ & $\sqrt{ }$ & & $\sqrt{ }$ & & $\sqrt{ }$ & & $\sqrt{ }$ & & 5 \\
\hline Bruceine B & $\sqrt{ }$ & $\sqrt{ }$ & & $\sqrt{ }$ & & $\sqrt{ }$ & & $\sqrt{ }$ & & 5 \\
\hline Bruceine C & $\sqrt{ }$ & & & & & $\sqrt{ }$ & & $\sqrt{ }$ & & 3 \\
\hline Bruceine D & $\sqrt{ }$ & $\sqrt{ }$ & & & & $\sqrt{ }$ & & $\sqrt{ }$ & & 4 \\
\hline Bruceine E & & & & & & & & & $\sqrt{ }$ & 1 \\
\hline Bruceine $\mathrm{G}$ & $\sqrt{ }$ & $\sqrt{ }$ & $\sqrt{ }$ & & $\sqrt{ }$ & $\sqrt{ }$ & & $\sqrt{ }$ & & 6 \\
\hline Bruceoside A & $\sqrt{ }$ & & & & $\sqrt{ }$ & $\sqrt{ }$ & & $\sqrt{ }$ & $\sqrt{ }$ & 5 \\
\hline Bruceoside B & & & & & & & & & $\sqrt{ }$ & 1 \\
\hline Bruceoside C & $\sqrt{ }$ & $\sqrt{ }$ & & & & $\sqrt{ }$ & & $\sqrt{ }$ & & 4 \\
\hline Daucosterol & & & & & & & & & & 0 \\
\hline Dehydrobruceantinol & $\sqrt{ }$ & & & & & $\sqrt{ }$ & $\sqrt{ }$ & $\sqrt{ }$ & & 4 \\
\hline Dehydrobruceine A & $\sqrt{ }$ & & & & & $\sqrt{ }$ & & $\sqrt{ }$ & & 3 \\
\hline Dehydrobruceine B & $\sqrt{ }$ & & & & & $\sqrt{ }$ & & $\sqrt{ }$ & & 3 \\
\hline Dehydrobrusatol & $\sqrt{ }$ & & & & & $\sqrt{ }$ & & $\sqrt{ }$ & & 3 \\
\hline Yadanziolide A & $\sqrt{ }$ & $\sqrt{ }$ & & & & $\sqrt{ }$ & & $\sqrt{ }$ & & 4 \\
\hline Yadanziolide B & $\sqrt{ }$ & $\sqrt{ }$ & & & $\sqrt{ }$ & $\sqrt{ }$ & & $\sqrt{ }$ & & 5 \\
\hline
\end{tabular}

value of each conformation result which was successful if RMSD obtained is no more than known as the coordinates between the original $2 \AA .{ }^{19}$ Control docking result demonstrated pose of the ligand in the target binding site that the RMSD value observed was $1.32 \AA$ and the docked pose after the simulation. which means that the docking parameters set RMSD value is applied as a condition to up were acceptable and therefore could be evaluate the validity of the control docking employed for virtual screening experiments process in which a control docking would be upon compounds from $B$. javanica.

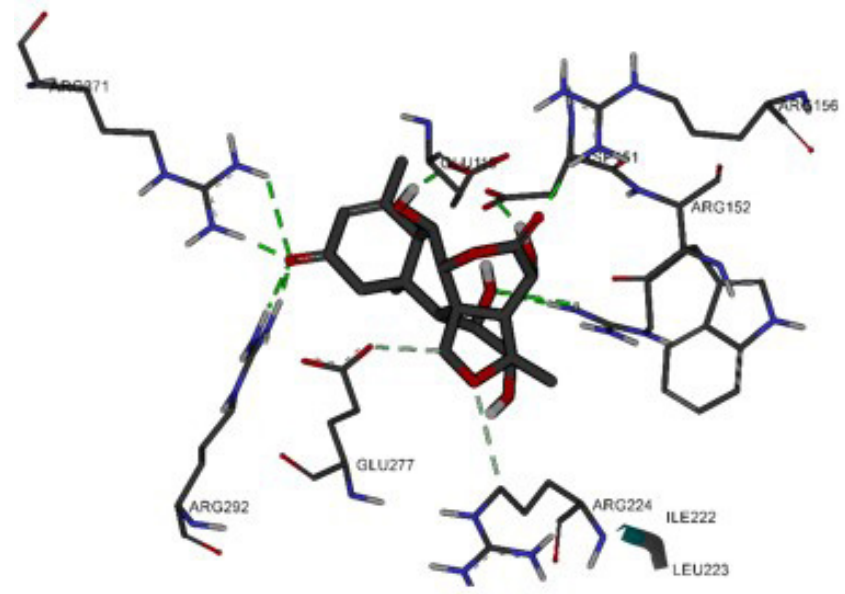

Figure 2. 3D docking pose of brucein G. Hydrogen bonds were presented in dashed lines. The functional group of these compounds interacts via hydrogen bonds with Asp151, Arg152, Glu119, Glu277, Arg292 and Arg371. 


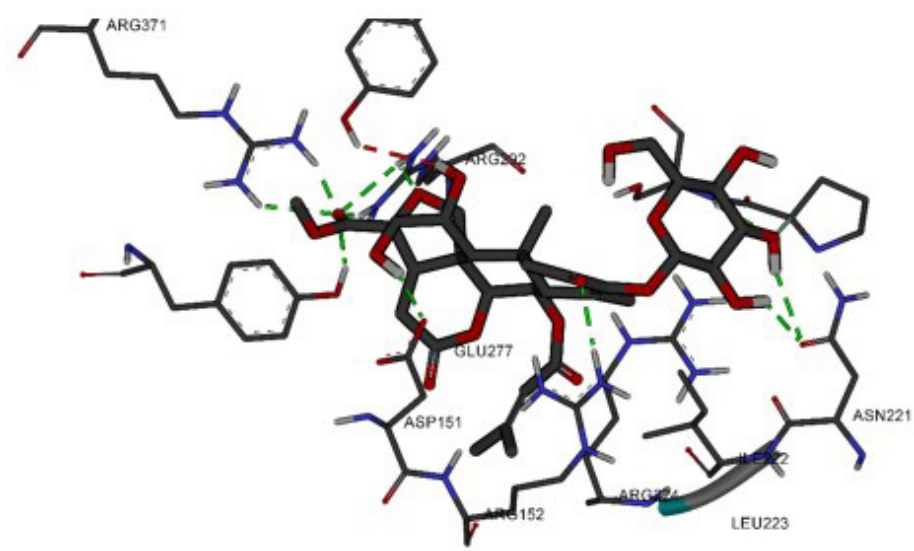

Figure 2. 3D docking pose of bruceoside $\mathrm{C}$. The hydrogen bonds interactions were presented in dashed lines. The functional group of these compounds interacts via hydrogen bonds with Asp151, Arg152, Arg292 and Arg371

The results (Table 1) showed that the free energy of binding of the compounds varies from $-9.10 \mathrm{kcal} / \mathrm{mol}$ to $-5.81 \mathrm{kcal} /$ mol. Top 5 compounds in which values are comparable with the binding free energy of OTV as a control ligand $(-9.30 \mathrm{kcal} / \mathrm{mol})$ were chosen. The selected compounds were bruceoside $\mathrm{B}$, bruceantinol, bruceine $\mathrm{G}$, bruceoside $\mathrm{C}$, and bruceantin with the free energy binding value of $-8.65,-8.41,-8.39$, and $-8.17 \mathrm{kcal} / \mathrm{mol}$, respectively. These values may theoretically mean that those selected ligands may demonstrate molecular interactions that are as good as OTV in terms of the binding to NA. Visualization of docked conformation was applied to investigate the hydrogen bonding as it is the most crucial intermolecular interaction between ligand and receptor.

The virtual screening results showed that although bruceoside $\mathrm{B}$ possessed the lowest free energy binding, however, it only had one hydrogen bonding with Tyr347 meanwhile bruceantinol with the secondlowest energy binding, had less interaction with the NA binding site compare to bruceine $\mathrm{G}$ and bruceoside $\mathrm{C}$. Thus the analysis showed that bruceine $\mathrm{G}$ and Bruceoside $\mathrm{C}$ gave the lowest binding energy and most preferred interactions. Based on the 3D docking pose of each compound, the activity of brucein $\mathrm{G}$ and bruceoside $\mathrm{C}$ were predicted by observing the hydrogen bond interactions happened between the ligands and NA active site mainly between their carboxyl and hydroxyl groups and the binding site (Figure $2 \& 3$ ). Brucein $\mathrm{G}$ contains a carboxyl group which formed hydrogen bonds with $\operatorname{Arg} 292$, Arg371, and Glu227, similar to OTV. On the other hand, bruceoside $\mathrm{C}$ included a carboxyl group which interacted via hydrogen bonds with the guanidine group of Arg152, and hydroxyl groups which established hydrogen bonds interaction with Arg292 and Arg371. Arg292 and Arg371 are two of three arginine triad known as highly critical arginine residues in the binding site of NA which enables the conformational change of the ligand and is believed to be very important in the catalysis of substrate. ${ }^{20}$ Furthermore, brucein $\mathrm{G}$ also formed hydrogen bond interactions with Asp151, Arg152, Glu119 and bruceoside C with Asp151, which gave contributions to the total free energy binding between the ligands and NA binding site.

\section{Conclusion}

Nineteen compounds from $B$. javanica were successfully docked and then analysed based on their free energy binding and intermolecular interactions with NA binding site. Two of the selected ligands, namely bruceine $\mathrm{G}$ and bruceoside $\mathrm{C}$, gave the lowest binding energy value with the most preferred interactions. Further study can be conducted to investigate the antiviral activity of these compounds via in vitro bioassay using 2'-(4-Methylumbelliferyl)- $\alpha$ $\mathrm{D}-\mathrm{N}$-acetylneuraminic acid (MUNANA) as fluorogenic substrate. 


\section{Acknowledgements}

We want to thank the Directorate of Research, Community Service and Innovation Universitas Padjadjaran for the funding, and Computational Chemistry and Bioinformatics Laboratory Universitas Padjadjaran, to provide computing facilities for this work.

\section{References}

1. Wonderlich ER, Swan ZD, Bissel SJ, Hartman AL, Carney JP, O'Malley KJ, et al. Widespread Virus Replication in Alveoli Drives Acute Respiratory Distress Syndrome in Aerosolized H5N1 Influenza Infection of Macaques. J Immunol. 2017;198(4):1616-26.

2. Smetana J, Chlibek R, Shaw J, Splino $\mathrm{M}$, Prymula R. Influenza vaccination in the elderly. Human Vaccines \& Immunotherapeutics. 2018;14(3):540-9.

3. WHO. Cumulative number of confirmed human cases for avian influenza A(H5N1) reported to WHO, 2003-2019 2019 [updated 25 November 2019. Available from: https://www.who.int/influenza/ human animal interface/2019 1125 tableH5N1.pdf?ua=1.

4. UyekiTM,Peiris M. NovelAvianInfluenza A Virus Infections of Humans. Infect Dis Clin North Am. 2019;33(4):907-32.

5. CDC. Highly Pathogenic Asian Avian Influenza A (H5N1) in People 2015 [updated 18 March 2015. Available from: https://www.cdc.gov/flu/avianflu/h5n1people.htm.

6. Welkers MRA, Pawestri HA, Fonville JM, Sampurno OD, Pater M, Holwerda M, et al. Genetic diversity and host adaptation of avian H5N1 influenza viruses during human infection. Emerging Microbes \& Infections. 2019;8(1):262-71.

7. Mangiri A, Iuliano AD, Wahyuningrum Y, Praptiningsih CY, Lafond KE, Storms $\mathrm{AD}$, et al. Physician's knowledge, attitudes, and practices regarding seasonal influenza, pandemic influenza, and highly pathogenic avian influenza A (H5N1) virus infections of humans in Indonesia. Influenza and Other Respiratory Viruses. 2017;11(1):93-9.
8. McKimm-Breschkin JL. Influenza neuraminidase inhibitors: antiviral action and mechanisms of resistance. Influenza Other Respir Viruses. 2013;7 Suppl 1:2536.

9. Gubareva LV, Kaiser L, Hayden FG. Influenza virus neuraminidase inhibitors. Lancet. 2000;355(9206):827-35.

10. Vavricka CJ,LiQ, WuY, Qi J, Wang M, Liu $\mathrm{Y}$, et al. Structural and functional analysis of laninamivir and its octanoate prodrug reveals group specific mechanisms for influenza NA inhibition. PLoS Pathog. 2011;7(10):e1002249.

11. Samson M, Pizzorno A, Abed Y, Boivin G. Influenza virus resistance to neuraminidase inhibitors. Antiviral Res. 2013;98(2):174-85.

12. Kannan S, Kolandaivel P. Antiviral potential of natural compounds against influenza virus hemagglutinin. Comput Biol Chem. 2017;71:207-18.

13. Gasparini R, Amicizia D, Lai PL, Bragazzi NL, Panatto D. Compounds with antiinfluenza activity: present and future of strategies for the optimal treatment and management of influenza. Part II: Future compounds against influenza virus. J Prev Med Hyg. 2014;55(4):109-29.

14. Purwitasari N. Aktivitas Antiviral Influenza A Subtipe H5N1dari Ekstrak Brucea javanica L.Merr. Planta Husada. 2014;2(2):27-30.

15. Ikram NKK, Durrant JD, Muchtaridi M, Zalaludin AS, Purwitasari N, Mohamed N, et al. A Virtual Screening Approach For Identifying Plants with Anti H5N1 Neuraminidase Activity. Journal of Chemical Information and Modeling. 2015;55(2):308-16.

16. Ye Q-M, Bai L-L, Hu S-Z, Tian H-Y, Ruan L-J, Tan Y-F, et al. Isolation, chemotaxonomic significance and cytotoxic effects of quassinoids from Brucea javanica. Fitoterapia. 2015;105:66-72.

17. Chen YY, Pan QD, Li DP, Liu JL, Wen YX, Huang YL, et al. New pregnane glycosides from Brucea javanica and their antifeedant activity. Chem Biodivers. 
2011;8(3):460-6.

18. Liu JH, Jin HZ, Zhang WD, Yan SK, H. SY. Chemical constituents of plants from the genus Brucea. Chemistry \& Biodiversity. 2009;6(1):57-70.

19. Xiao W, Wang D, Shen Z, Li S, Li H. Multi-Body Interactions in Molecular Docking Program Devised with Key
Water Molecules in Protein Binding Sites. Molecules. 2018;23(9).

20. Gubareva LV, Robinson MJ, Bethell RC, Webster RG. Catalytic and framework mutations in the neuraminidase active site of influenza viruses that are resistant to 4-guanidino-Neu5Ac2en. J Virol. 1997;71(5):3385-90. 